Rapp. Grønlands geol. Unders. 88, 5-10 (1979)

\title{
THE PROTEROZOIC SANDSTONES BETWEEN HEILPRIN LAND AND MYLIUS-ERICHSEN LAND, EASTERN NORTH GREENLAND
}

\author{
J. D. Collinson
}

\section{Introduction}

The oldest sediments of eastern North Greenland are a series of sandstones, whose base is not seen and whose top is a surface of unconformity above which are sediments which pass without apparent break into rocks of Cambrian age. These lowest sandstones were initially included by Koch (1929) in his Thule Formation by comparison with sediments lying between crystalline basement and Cambrian sediments in North-West Greenland. They were subsequently designated as 'Thule Group' by Haller (1971), who regarded them as the autochthonous representatives of the pre-Carolinidian sedimentary cycle. The absence of any direct links with the Thule Basin leads to a preference here for the informal term Proterozoic sandstones.

The sandstones have only previously been examined at both ends of the present study area. In the north-west, in Heilprin Land, the lowest sandstones were called the 'Inuiteq Sø Formation' (Jepsen, 1971) whilst in the south-eastern part of Mylius-Erichsen Land, Adams \& Cowie (1953) referred to the lowest sandstones as the 'Norsemandal Sandstone'. The broad lithological similarity and the occurrence of extensive igneous intrusions, and the truncation of the sequence by an unconformity overlain by younger Precambrian (possibly Eocambrian) sediments suggested the reasonable correlation of Inuiteq Sø Formation and Norsemandal Sandstone (Jepsen, 1971; Dawes, 1976).

Fieldwork in 1978, mainly in J. C. Christensen Land, allowed this correlation to be tested and also facilitated a fuller description of the sediments.

\section{Stratigraphical relationships}

The base of the older sandstones of eastern North Greenland is nowhere exposed, though it is assumed that it rests on crystalline basement beneath the Inland Ice, at some distance to the south-west. Such sandstones are apparently absent in the Victoria Fjord area although Cambrian sediments lying directly on crystalline basement include huge boulders of 'older' sandstones (Peel, this report). The sandstones throughout eastern North Greenland are characterised by very abundant intrusions of dolerite, granophyre and 'flow breccia' (Jepsen \& Kalsbeek, this report). The sandstones and their associated intrusives are overlain with apparent conformity by a thick sequence of basaltic extrusives in J. C. Christensen Land and Valdemar Glückstadt Land (map 1). North of Independence Fjord the intruded sandstones are overlain by the Morænesø Formation. This younger sequence of breccias, sandstones 


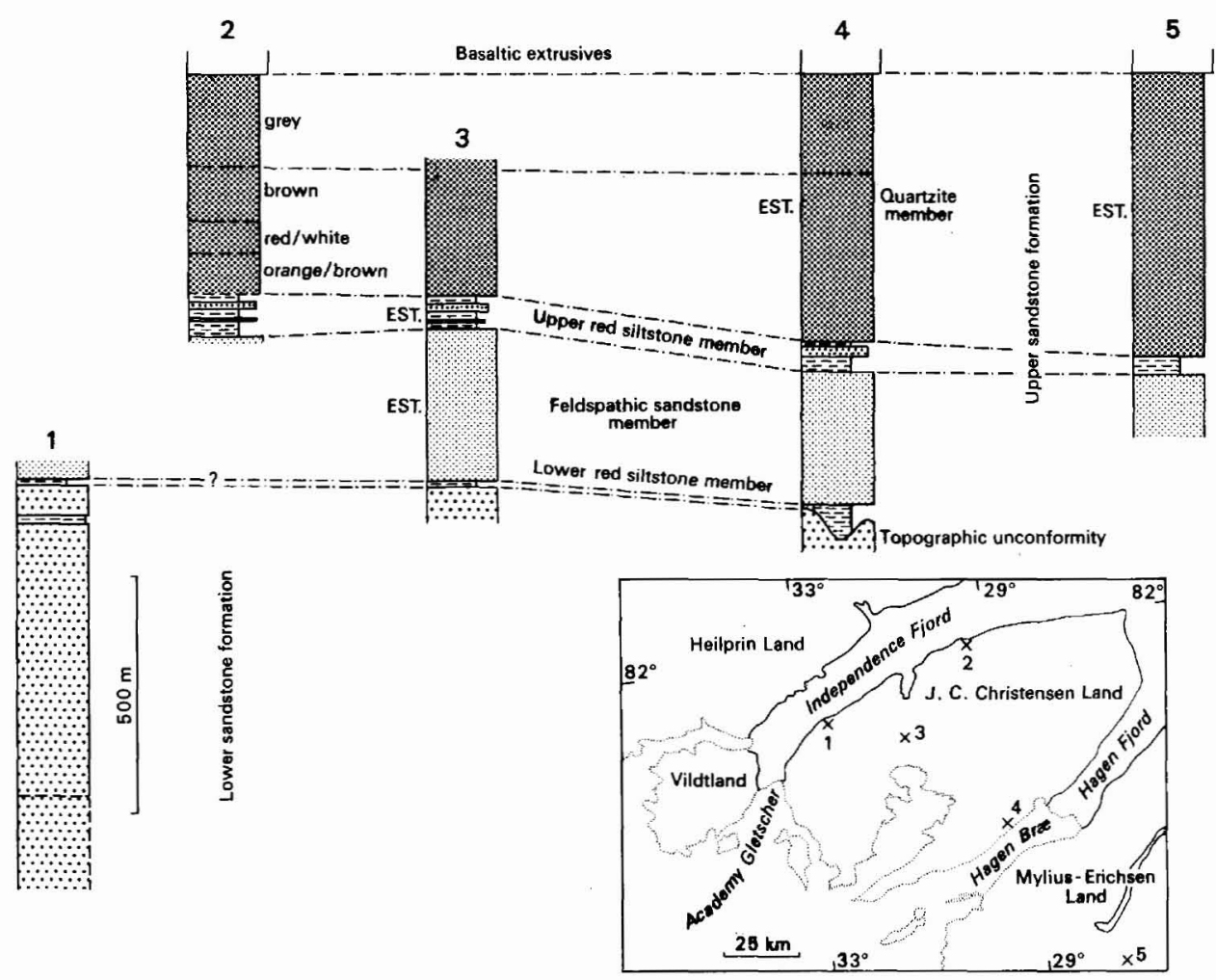

Fig. 1. Representative sections in the sandstones of J. C. Christensen Land and Mylius-Erichsen Land. The base of the basalt extrusives is used as a datum and correlations are indicated. EST. indicates an estimated thickness.

and stromatolitic dolomites rests on an unconformity which is mainly recognised by a relief of up to at least $60 \mathrm{~m}$. Across J. C. Christensen Land and Valdemar Glückstadt Land, the basalts are overlain, unconformably by sediments referred to the Campanuladal Formation (Clemmensen, this report) which correlate generally with the Campanuladal Sandstones and Limestones of Adams \& Cowie (1953) recognised in the Danmark Fjord area.

Within the older sandstones, the only stratigraphical subdivision previously recorded is the occurrence of " marine, semi-pelitic" sediments below the main sandstone sequence on Vildtland (Haller, 1971). These finer sediments are regarded by Haller as the only autochthonous equivalents of sediments otherwise confined to the Carolinidian fold belt. Haller's documentation of the occurrence is rather vague and, as the area in question was not visited in 1978, the nature of this possible lower division must remain doubtful.

Field work in 1978 has shown that the Proterozoic sandstone sequence can be divided into five mappable units and that there is, within the sequence, an unconformity of some importance (fig. 1). The sediments below the unconformity occur mainly in the north-west of the area (map 1) and are equivalent to the Inuiteq Sø Formation (Jepsen, 1971). In contrast, the sediments above the unconformity occur mainly in the south-east and therefore include the Norsemandal Sandstone (Adams \& Cowie. 1953). No new formation names are presently 
proposed, because of some uncertainty about the identity and correlation of siltstone units north of Independence Fjord. Informal terms are used in the following description of the sequence.

\section{The lower sandstone formation (Inuiteq Sø Formation)}

This formation consists of mainly feldspathic sandstones which are at least $1 \mathrm{~km}$ thick. Their base has not been seen but the possibility of an underlying finer grained formation cropping out in Vildtland, as mentioned by Haller (1971), should be borne in mind. About $800 \mathrm{~m}$ of these sandstones are seen in cliffs east of Academy Gletscher. However, the abundance of dolerite intrusions and the lack of mappable horizons makes calculation of a total thickness very difficult and more detailed mapping impossible. Exposures of this formation are confined to Heilprin Land, Vildtland, and the western part of J. C. Christensen Land.

The formation is a monotonous sequence of cross-bedded and horizontally bedded sandstones within which no order is obvious. In J. C. Christensen Land, the highest sandstones are rather quartzitic, but in the supposedly lower sandstones of the area around Inuiteq $S ø$ and $\varnothing v$ ve Midsommersø, the feldspar content can be as high as about 20 per cent. Thin silty interbeds commonly show desiccation cracks and wave-rippled bedding planes are quite common. Much of the sequence suggests a shallow marine environment but the evidence of emergence suggests episodes of regression or possibly conversion of the area to a shallow lake. Well rounded sand grains suggest that wind transport may have been important from time to time.

Between Inuiteq Sø and Øvre Midsommersø, a unit of interbedded red siltstones and paler thin sandstones crops out in several places. The unit is up to at least $30 \mathrm{~m}$ thick and bedding planes show abundant wave ripples, desiccation cracks and salt pseudomorphs. This unit lies close below the unconformity and its outcrop is fragmentary, being confined to the floors and sides of valleys, while the hills are capped with the overlying Morænesø Formation. It is therefore difficult to map and correlation is uncertain. It could be either a siltstone unit within the lower sandstone formation or it could possibly correlate with the lower of two siltstones recognised in the upper sandstone formation of J.C.Christensen Land. This unit was included in Jepsen's (1971) initial description of the Inuiteq Sø Formation. If it occurs within the lower sandstone formation as defined here, there is no complication. If, however, it corresponds to the lower siltstone member of the upper sandstone formation, the equation of lower sandstone formation with Inuiteq Sø Formation would break down. More work in the area between Inuiteq $\boldsymbol{\emptyset}$ and Øvre Midsommersø should resolve this question.

\section{The upper sandstone formation (includes Norsemandal Sandstone)}

This formation rests with marked unconformity upon the underlying lower sandstone formation. No perceptible angular discordance is seen but instead the surface of the unconformity is characterised by a spectacular topography. Within the formation, stratigraphical subdivisions are clear and the various members can be mapped with confidence across $\mathbf{J}$. C. Christensen Land. The upper units can also be traced into Mylius-Erichsen Land where it 
would seem from reconnaissance that the uppermost member, the quartzite member, corresponds to the Norsemandal Sandstone of Adam \& Cowie (1953). In J. C. Christensen Land, the intensity of intrusions is less in the upper sandstone formation than it is the lower sandstone formation but in Mylius-Erichsen Land,where only the upper sandstone formation is exposed, intrusions are abundant, even in the uppermost quartzite member.

Four mapping members are recognised, one of which can be further subdivided (fig. 1):

(4) Quartzite member $\left\{\begin{array}{l}\text { Grey weathering unit } \\ \text { Red-brown weathering unit }\end{array}\right.$

(3) Upper red siltstone member

(2) Feldspathic sandstone member

(1) Lower red siltstone member

\section{Lower red siltstone member and the topographic unconformity}

The basal unconformity upon which the member rests is only recognised as such on the north side of Hagen Bræ where it is intermittently exposed over some $20 \mathrm{~km}$. The unconformity involves no angular divergence but is recognised by a complex topographic surface cut into the lower sandstone formation which must, therefore, have been lithified prior to erosion. A relief of at least $70 \mathrm{~m}$ is seen with valley sides cutting down locally at high angles $\left(20^{\circ}\right)$. The erosion surface is sometimes draped by flank beds comprising sandstone blocks set in a sandstone matrix. These dip roughly parallel to the erosion surface. The flank beds or the erosion surface itself are draped by red siltstones and by interbedded red siltstones and pale feldspathic sandstones (fig. 2). The total thickness of siltstones and interbedded sediments varies from less than $10 \mathrm{~m}$ on palaeo-hill tops to over $70 \mathrm{~m}$ in palaeo-valley fills. To the north, in J. C. Christensen Land, the member is thinner, $3-4 \mathrm{~m}$ of sediment being seen in several localities. It is possible that the member may be locally absent.

\section{Feldspathic sandstone member}

The member is of the order of $300 \mathrm{~m}$ thick and appears to thin slightly from north to south across J. C. Christensen Land. In its lower part it is feldspathic with up to $c .20$ per cent pink feldspar. This is reduced in abundance upwards and the upper parts of the member approach a quartzite in composition. There appear to be some lateral facies changes within the member. At Hagen Bræ, the lowest sandstones are fluvial channel bodies about $15 \mathrm{~m}$ thick which pass upwards into more homogeneous cross-bedded red and white striped sandstones of possible shallow marine origin. In the northern part of J. C. Christensen Land, the lowest sandstones are thinly and irregularly bedded. These pass upwards into more cross-bedded sandstones but without the intense red colouration seen in the south.

\section{Upper red siltstone member}

This is the key mapping unit and is a sequence of interbedded red siltstones and paler quartzitic sandstones. The overall thickness of the member decreases from north to south 


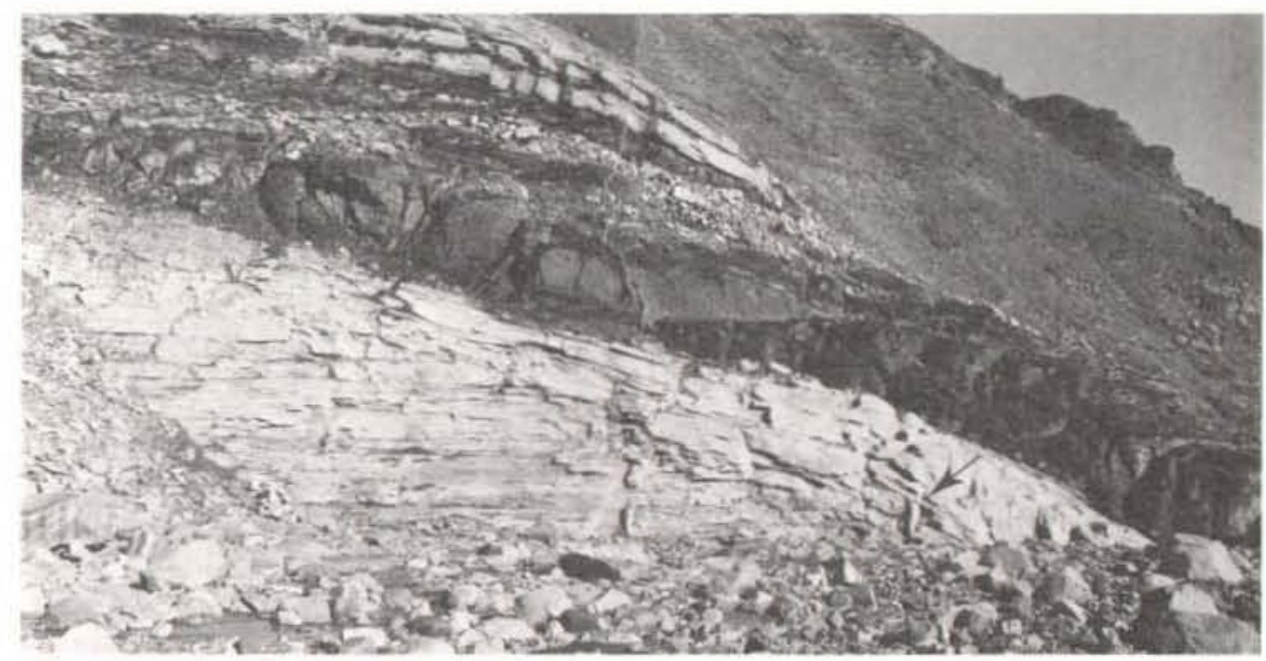

Fig. 2. Topographic unconformity cut into the top of the lower sandstone formation. North side of Hagen Brz. The horizontally lying sandstones are immediately overlain by dipping sandy flank beds which in turn are draped by red siltstones of the lower red siltstone member. Figure for scale (marked by arrow).

across J. C. Christensen Land from $90 \mathrm{~m}$ at Independence Fjord to $65 \mathrm{~m}$ at Hagen Bra. Reconnaissance in Mylius-Erichsen Land suggests that the thinning may continue to the south-east but further work is needed to establish this.

\section{Quartzite member}

This sequence of cross-bedded and rippled quartzites shows little evidence of any vertical or lateral facies changes though there is a fairly clear vertical colour variation in $\mathrm{J}$. C. Christensen Land and the western part of Mylius-Erichsen Land. A lower, red weathering, unit is consistently overlain by a grey weathering unit which extends upwards to the base of the basalts. The pattern of colour variation seems to break down to the south-east. A generally shallow marine environment of deposition seems likely.

\section{Environment of deposition}

The whole of the sandstone sequence, both above and below the unconformity was laid down in very shallow water or in subaerial conditions involving wind transport of sand. Whilst there is good evidence of local fluvial activity in the sandstones immediately above the unconformity, the rest of the sequence shows a very subtle change of bedding which probably reflects a rather unusual depositional environment, sometimes shallow marine, sometimes a lake, at other times a dry surface over which wind blown sand moved to accumulate as dunes. Detailed sedimentological analysis is yet to be done but an intuitive 
environmental model envisages an intracratonic lake, perhaps similar to modern Lake Chad, but subjected to periodic marine incursions, during which tidal currents were sufficiently strong to transport sand as large bed forms. The episode of lithification and uplift which gave rise to the unconformity within the sandstones does not appear to have altered the overall environment of deposition.

\section{Palaeogeography and nomenclature}

The intra-cratonic basin in which the Proterozoic sandstones of eastern North Greenland accumulated may have formed on the edge of the Carolinidian 'geosyncline' which lay to the east. The absence of clastic sediments in the Victoria Fjord area seems to weaken any links between the eastern North Greenland basin and the Thule Basin of North-West Greenland. It may well be that the sediments of the two areas accumulated at different times in geographically and tectonically distinct basins. On those grounds use of the term 'Thule Group' in North-East Greenland should be discontinued, as suggested by Dawes (1976).

No new nomenclature is proposed at present but it seems likely that a new scheme will eventually be necessary for these sediments. This must, however, await completion of the present phase of work.

\section{References}

Adams, P. J. \& Cowie, J.W. 1953: A geological reconnaissance of the region around the inner part of Danmarks Fjord, Northeast Greenland. Meddr Grønland 111,7, 24 pp.

Dawes, P. R. 1976: Precambrian to Tertiary of Northern Greenland. In Escher, A. \& Watt,W.S. (edit.) Geology of Greenland, 249-303. Copenhagen: Geol. Surv. Greenland.

Haller, J. 1971: Geology of the East Greenland Caledonides, 413 pp. London: Interscience.

Jepsen, H. F. 1971: The Precambrian, Eocambrian and early Palaeozoic stratigraphy of the Jørgen Brønlund Fjord area, Peary Land, North Greenland. Bull. Grønlands geol. Unders. 96 (also Meddr Grønland 192,2) 42 pp.

Koch, L. 1929: Stratigraphy of Greenland. Meddr Grønland 73 (2),2, 205-320. 